\title{
Matrimony relations and business in a fishing migrant community (periphery of Pointe-Noire, Congo -Brazzaville)
}

\begin{abstract}
This paper examines the entrepreneurial activities of female migrants in the informal artisanal fishing sector along the coastal line of Congo-Brazzaville. It shows the extent to which these women have achieved an insertion into a market niche, fish smoking, which builds on the livelihoods of co-ethnic migrant fishermen. Women rely on tile fish supplied by male migrants including their husbands to run their fish smoking activities. In return, they re-invest part of the proceeds in their husbands' fishing business. This interdependency of livelihoods reflects a reconstruction of gender-relations within the household which links matrimony to migration as an assetaccumulation strategy. The observed patterns in enterprising amply support the view that vulnerable households are capable of mobilising additional labour - in this case women's labour - in order to diversify their sources of income. The paper also demonstrates how inter-spouses partnering generate cohesion within the household and provides a mechanism for pooling income and other resources and for sharing business risks. In this regard, the household can be perceived as safety net and migration is indeed a strategy through which assets are accumulated in the host society. Little evidence has however come from the paper to suggest an effective emancipation and social autonomy on the side of the entrepreneurial woman. The relations of subordination seem to prevail, although less intense than before.
\end{abstract}

This paper examines the entrepreneurial activities of female migrants in the rural periphery of the city of Pointe-Noire, located in the coastal zone of CongoBrazzaville. More specifically, it interrogates the extent to which migrating to a foreign destination opens up some opportunities to women of inserting into a market niche in the informal sector of the host country. Entrepreneurship among African women is not a novelty. Nor is the participation of women in migration. Indeed, from the numerous studies conducted on the female migration in developing countries, it emerges a consensus that women are as mobile as men (United Nations, 1993; Adepoju, 2008; Preston-White et al., 2006). In the same vein, female-owned trading businesses in the local economies have always been present in the portfolio of assets for livelihoods of many African families. This is visible through the predominance of women in most market places of African cities where goods are transacted (Brown, 1995). 
There is however little conceptual and empirical insights in the field of migration and development about the experiences of female migrants with entrepreneurs hip beyond national borders. The point made by Pingle (2008) is given credence here when she argues that literature on the relationship between migration and entrepreneurs hip tends to focus on male migrants and neglects female experiences. More specifically, this paper addresses a few gaps in the literature by investigating ways in which female migrants establish enterprises abroad, set up ventures with coethnic members in specific activities. It also looks at the characteristics of enterprises they create and the transactions organized (or outcomes exchanged) in their entrepreneurial activities in partnership. These are less researched and documented migratory issues. Equally, the extent to which they resort to social support outside the domestic space is central to the investigation. Placing the analytical focus on the artisanal fishing industry, the following questions are therefore addressed: to what extent the structure of opportunities at destination creates the conditions for enterprising among female migrants in a lucrative market of the informal sector? What are the linkages of female migrant entrepreneurship with the economic activities undertaken by their husbands? To what strata of social networks migrant women prominently resort to in establishing and running business? What effect does entrepreneurship produce in the emancipation of women and reconfiguration of gender relations at the household level? To answer these questions and capture the nature of entrepreneurial activities and trajectories, a case study of migration experiences of women in Congo-Brazzaville is proposed here. In addition to this introduction, there are six more sections in the paper. The second proposes a guiding theoretical framework outlined with a special focus on the role of social networks in gender variations of entrepreneurial activities . Data and methods are presented in the third section. The fourth section provides a migratory background to entrepreneurial female migration to highlight its connections with the sexual division of labour. The fifth section examines the patterns of organization among migrant women by looking ways in which they negotiate enterprising with their family responsibilities. The sixth section looks at the position of women in the matrimonial relations at the household level. The last section proposes a discussion on the extent to which enterprising generates changes in their subordination to men.

\section{Theoretical framework}

The methodological perspective used in this study is both exploratory and interpretive making use of in-depth interviews carried out conjointly with sited observations of daily activities. It is important to recognize the absence in the literature of any specific theory about migrant entrepreneurship applicable to female migrants within the context of Africa. The same can be said about the general considerations on immigrant entrepreneurs in the broader context, which do not explicitly distinguish female from male entrepreneurs. However one can still borrow, on the one hand, from the general literature on female entrepreneurship, irrespective of migration status, and, on the other, from that of entrepreneurship among migrants of the same origin to derive some combined elements of theory construction to understand the trajectories in female migrant entrepreneurship and its associated effects on women involved. The effort required in this theoretical exercise results in this section being more detailed for the sake of argument construction. Theories of interest here are those built around social 
capital, networks and migrant entrepreneurial activity (Light and Parminder, 1993; Massey et al.. 1999; Castells and Miller 2003), which share many common arguments. A point to start from is the recognition of male-female differences in enterprising though the empirical evidence to come will not systematically compare men to women. Inasmuch as strong similarities can be drawn between the two sexes, it is also admitted that in many aspects female entrepreneurs display motivations, levels of skills in management and professional trajectories that are markedly different from those of their male counterparts (Hisrich and Gudida, 1986). Their decision to establish business is strongly driven by the desire to achieve personal autonomy and emancipation in order to escape from precarious economic activity exacerbated by all types of gender-based discrimination. The start-up capital too is an element of differentiation. According to Carsrud and Olm (1986), entrepreneurial women heavily rely on their social networks to acquire the necessary capital rather from formal institutions. This acquisition often comes with hurdles though the same can be said for men. From a professional point of view, women tend to venture in those activities strongly linked to petty trade and personal services for which the requirement in assets and human development falls low and previous experience is not demanded. In fact, the literature tends to depict businesses owned by women of much smaller size and lower return achievers (Minniti and Naidi, 2010). Contrary to men, women are seen to be less prone to risk taking and opportunity perception (Minniti and Naidi, 2010). It is perhaps because of these characteristics that businesses owned by women tend to operate in the informal sector where women are faced with more than ever opportunities in that sector. Interestingly, Hisrich and Gudida (1986) look at this as a female advantage, arguing that the creation of business grows faster among women than among men because of the wider range of opportunities in the informal sector. According to the same authors, social networks play a different role along the gender lines. Contrary to men, female entrepreneurs draw their support group for start capital in a certain order: first is the husband, second are relatives and close friends and third are business partners. Finally it is also noted that women heavily rely on different layers of other sources to obtain support and information such as professional associations and women groups.

Referring to network migration theory, scholars view entrepreneurship as one of the major channels through which many of the more successful migrant groups achieve economic advancement and social mobility (Razin, 1993). Entrepreneurs as innovators and risk takers play a critical role in creating jobs for other people, providing services and creating new products for the market through a combination of old or new material (Dana and Moris, 2009). Aspects which play a critical role in this achievement include ethnicity, class resources, cultural practices in business management, characteristics of the host country, and specificity of the location to name but a few (Light and Rosenstein, 1989). The dynamics of interaction of the locations of origin and destination with migrants also influences entrepreneurial behaviour. A study conducted by Vinogradov and Gabelko (2008) in reference to Russia suggests that female immigrants (as compared to non-migrant females) are more likely to demonstrate intentions to start a business, in addition to possessing relatively large amount of specific human capital, social capital and self-confidence relevant for entrepreneurship. These authors define specific human capital in terms of know-how acquired outside formal mechanisms of training. Human capital may be either general in terms of year of education or specific in terms of its 
applicability to a specific sector (Bosma and Thurik, 2004). In the case of female entrepreneurship, the amount of specific human capital is especially important (Vinogradov and Gabelko, 2008). The importance of knowing other entrepreneurs has been emphasized in the taking of a decision to start a business in the place of destination (Arenius and Minniti, 2005). Those lacking social networks cannot afford to migrate and are the least likely to leave the country. Those with a certain social capital can more easily integrate the opportunity structure in the destination place.

The African urban context is conducive for entrepreneurship within the migrant community in the informal sector, as is the case in other cities of the South (see for example the study of Florez (2006) on Latin America) . Brown (1995) cites ILO reports which indicate that African women make up at least half of the total numbers of traders involved in the informal sector as entrepreneurs. As the employment crisis affecting the labour markets of most African countries deepens, so is the difficulty of finding a job in the mainstream economy (Adepoju, 2008). Self -employment is often the sole option available to migrants in search of employment. Because of its attractiveness to migrants that eavily rely on family and ethnic ties, such a small business environment contributes mostly to the formation of migrant entrepreneurial enclaves. Sites where migrants have clustered facilitate entrepreneurial activities for large number of male and female migrants who otherwise lacked formal qualifications to enter the mainstream economy (Dana and Moris, 2009). Moreover, competition is hard due to the general lack of employment opportunities for locals as well. In general, migrant entrepreneurs in the informal urban economy often resort to their personal relations, of which kinship is central, to establish business within or outside community of belonging. The role of social networks has been centralized in the theories focus ing on intergroup variations in entrepreneurial activities (Light and. Parminder, 1993). In the formation of what Razin ( 1993) calls "enclaves of entrepreneurial activity ", the preservat ion of ethnic or community ties is a unifying feature driven by family ties, trust relations, language, and culture. Migrants' entrepreneurial activity enclaves can be regarded as a web of informal networks which serve as channels for recruiting labourers, gather ing information, transmitting skills needed in the insertion into a particular market niche (Razin, 1993). It is indeed in this caveat that these enclaves give rise to informal institutions based on ethnic or community of origin of migrants. Razin argues that such institutions relate female and male migrants within entrepreneurial-shared practices. For example, recently arrived migrants acquire entrepreneurial skills by working under the mentorship or the guidance of a senior migrant in the business. The husband may as well play such a role by motivating and supporting his spouse to venture in this business.

From the theoretical considerations above, three analytical directions of interest for this paper arise. The first direction is that of niches in which women migrants insert to set up enterprises in the destination economy. The second direction is the extent to which their entrepreneurial trajectories build on the existing migrant economy established by their male counterparts in the host country. Finally, the third direction points to the effect of their entrepreneurial activities on intra-household relations in terms of decision-ma king or oneself emancipation. The last mentioned direction deserves further attention in this section. From the numerous studies produced on female migration, it is difficult to establish the extent to which mobility contributes to the emancipation or 
subordination of women migrants irrespective of their participation in the labour market. The least one can say is that there are mixed consequences - positive and negative - of female migration for the women involved and their families (Rodenberg, 1993). For example, with improved access to resources, female migrants in many migrant enclaves of Asia have been able to acquire greater power and status (Strauch, 1984). Such an induced social mobility may cause strains and conflicts within the household, but it also gives women a greater sense of their own worth and a stronger basis for selfesteem. Married women particularly may see their status enhanced. Radian (1988) in her study of married women migrants in Mexico City points out that earnings derived from their economic activity allow women to avoid conflict with their spouses by reducing the frequency with which they had to ask for money or argue about expenditures. Access to an independent income, irrespective of the amount, restores women' s selfimage and self-esteem. In fact, despite all the drawbacks of migration, living away from home is generally viewed by women themselves as "liberating", providing a degree of freedom and independence not always possible at home. Hugo (cited in United Nations, 1993) too makes the point that by becoming wage or income earners, such a change is likely to enhance the independence of women and to strengthen their role in decisionmaking within the family. The case study included in this paper explores the possibility of this enhancement. However, this view expressed by Hugo was long before called into question by Lu (1984) who cautioned that the degree of power held by the woman in the family is positively correlated with the level of her income as a proportion of total family income. In her study of couple migrants in Taiwan this author shows the persistence of gender inequalities and the power of the husband within the family (Lu, 1984). The author observed that regardless of whether migrant wives participate in the workforce, whatever their employment status, type of occupation, location of work or level of income, there were no significant differences in their power within the family or in the roles that they play. Lu also notes that working migrant women were not purposefully using their economic contribution to modify family structure or relations. Therefore it is not always the case that the wife's independent access to a cash income is related to her position of power in the household. Rodenburg (1993) argues that possible redefinitions of the roles of wives and husbands in household management also depend upon the characteristics of women's work. The prevailing gender hierarchies or asymmetries in migrant households may be reinforced for certain types of work (as pointed out by Roldan (1988) in the case of domestic service in Mexico City). Changes may be brought about by necessity but the traditional family ideal persists. Far from being representative of the myriad of female entrepreneurial activities, the case study is intentionally selected to illustrate contrasting yet complementary forms of enterprising ventures. West African women are participants in networks linking migrants with specific entrepreneurial skills in artisanal fisheries and business practices. These networks are relatively strong and enduring because of their capacity to generate and mobilize transnational and withincommunity resources from various sources. As is reported later, in this community of migrants, women's practices around fish smoking are directly linked to their husbands' fishing activities. As Dana and Moris (2009) put it, such a gender-based partnering may allow women to create ventures that are tied to the ethnic networks or enclave, and to a motivation to serve the ethnic community. 
Within the larger context of the host economy, the role of the informal economy appears to be of an especially salient consideration as evidenced in the section to follow. Most workers entering this sector include migrants from other countries who are unable to find employment in the informal sector. They are motivated by the search of income for survival, relying on their own indigenous resources to create work. These incomegenerating activities involve as many members of the household as possible, including women and children. It is well documented that the informal sector provides a milieu that generates specific human capital by facilitating apprentices hip at low costs, which subsequently promotes endogenous appropriate technologies and make use of local resources. The lack of financial capital, seen as a major constraint on informal activities, can be overcome by resorting to social capital. Women migrants often represent the bulk of informal sector labour supply. Informal micro-enterprises run by these women require little or no start-up capital. Brown comments that most of the informal sector producers in Africa are women who make use of the informal economy to get access to money denied to them by their husbands. The case study presented in this paper explores these three theoretical directions. First a presentation is made of the context, data and methods that guided the empirical observations.

\section{Context, data and methods}

This section of the paper presents some relevant details on the setting of the case study and the methods structuring the analytical framework. The community has settled in the rural periphery adjacent to the coastal city of Pointe-Noire, the second major urban centre to the national capital Brazzaville. Population wise, this is a fast growing city with a booming oil industry. It also attracts massive inflows of migrants from various origins, especially from West Africa. Like many other economic capital cities in Africa, a large number of foreign entrants to the labour force either create their own employment or work for small family-owned enterprises. The city offers numerous income-generating opportunities to migrant entrepreneurs in fisheries, petty trade, retailing and services to name a few. The fishing community particularly settled in the coastal vicinity of the city not only for its proximity to the vast market of consumers found in Pointe-Noire, but also because of its appropriate environment for both informal fisheries and housing building. The fisheries examined in this article display all the characteristic of small-scale production activities operating in the informal sector. The response of the public authority to the growth of the fishing industry has tended to shift from incorporation, regulation to laisser-faire as documented elsewhere (Tati, 2006).

The empirical observations reported in this article draw from a study conducted within the framework of a multinational working group on land in the struggles for citizenship in Africa. The objective of the study carried out in Pointe-Noire was to establish the different ways the fishing community of migrant fishermen from West Africa (Benin and Togo) has over the years negotiated the occupancy of the space for both housing and income-generating activities from artisanal fishing in the coastal area of Congo-Brazzaville. The research covered as well women and gender roles in production activities within that community. The investigator visited several times the location where migrants have settled. Qualitative methods of data collection were used through in-depth interviews and site observations of informal enterprise owners among African migrants of both sexes during the period 2003-2006. It 
must also be indicated that follow-up data were gathered in January 2010 to take consideration of recent developments in the settlement. The specific details regarding the methods used in collecting information from the fishing canoes are given elsewhere (Tati, 2006). This article focuses on the inter-spouse transactional patterns in enterprising, a dimension not previously reported on. During the fieldworks, 255 home-based female entrepreneurs were visited to conduct the site observations and 20 married women were randomly selected to conduct in-depth interviews. Most women involved in fish smoking are married to fishermen. Unmarried women are family workers. The qualitative data collection methods were used to ground the insights in the practices and experiences of these female migrants with enterprising and matrimony. By doing so, it was possible to examine the range of changes brought by enterprising in the matrimonial relations from the point of view of power asymmetries within the gender relations as well as within the migrant community at large. From in-depth interviews of women, the investigator gathered information on the process they followed in learning the practice of fish smoking, the sourcing of fish, the diversification of income-generating activities, the relations with their husband and their participation in community-based activities. During these interviews, women were also invited to narrate the benefits derived from their activities both for their household welfare and personal emancipation. The leading questions were open-ended (unstructured) and the responses were manually recorded. To supplement the community survey, secondary quantitative data were also used. It must be mentioned here the difficulty the investigator encountered in accessing quantified information during the fieldworks. For example, apart of a very few informants, women interviewed were reluctant to reveal details on financial transactions with their husband. Statistics on fish loaded are either very unreliable or non-existent. This is mainly due to the fact that all the fishermen, including their spouses, operate informally.

Migratory background to the development of female-owned enterprises in the artisanal fishery since the early 1960s, African immigrant entrepreneurs from West Africa have been remarkably successful in the artisanal coastal fisheries (Tati, 2006). Migrants mostly come from Benin, Togo, Ghana and Nigeria. Fishing activities have rapidly developed as a consequence of migration flows resulting in large numbers of small enterprises . They first settled at the outskirts of the city of Pointe-Noire, but thereafter were relocated far away from the city. After many years of resistance and negotiation, they were evicted from what was their village to another space, at Diosso, 30 kilometres down the coast. Alike the situation in other coastal countries in Africa (see for example Ndiaye 2003; Diallo 2000), artisanal fisheries represent an important share of the catches for fish consumption in Congo. This sector is entirely under the domination of migrants from West Africa, as Congolese fishermen have either depopulated the area or lost interest in the activity due to the fierce competition imposed upon them by West Africans.

Population wise, the fishing migrant community has grown considerably in size: it is estimated today at around 85000 inhabitants all members considered. As one consequence of this demographic growth, the fishers' settlement has spatially 
expanded and housing has significantly been developed along the beach line. Both housing in the form of courtyards and economic activity have developed so rapidly that the settled sites of fishermen have been recently qualified as a new village in the rural locality of Diosso, nearby the city of Pointe-Noire. The migrants live inside courtyards that resemble to the traditional concessions found in most parts of West Africa. The social integration of members of this immigrant community is indeed impressive despite the illegal character of land property ownership and the volatile social environment that is periodically marked by xenophobic incidents. From the point of view of linkages with the city, the migrants are not disadvantaged. The road linking the settlement to the city is of good quality and, although in a rural area, it is classified as a national one. The migrants make use of this road to transport fish to the city markets for sale.

The development of coastal artisanal fishery has gone through considerable changes of which gender-related transactions have gained greater visibility, as reported in the section to come. Within the migrant community, the male immigrants in the coastal zone make their living as fishermen, and high-sea fishing remains an important activity for them today. Acquisition of land for housing has allowed some of them, though only a small number, to operate few non-fishing businesses. Many of these businesses are shops selling a variety of consumer goods from sugar and cooking oil to liquor and cigarettes. One natural outgrowth of this artisanal fishing industry has been an inward into the wholesale and distribution business of fresh fish across different places within the city of Pointe-Noire and the other major cities in the country. The mushrooming of fishing activities has resulted in the physical extension of the settlement site as illustrated by the proliferation of informal housing units in the nearby mangrove areas along the beach. Many fishing canoes catch stocks large enough to be able to sell en demi-gros (half wholesale) to local traders, who, in turn, re-sell in smaller quantities to market dealers and itinerant suppliers. At the other end of the commercial stream, numerous female migrants have also become involved in fish selling. These females are related to fishermen either through marital links or other kinship ties. Their livelihoods are diversified but they predominantly sell fish on the beach to customers from the city or in the market places around the city. With time they have established their own markets place at the outskirt place of the settlement. The first market of this kind established before relocation was named "Marche de la plage" (Beach Market Place). Although it is an informal community infrastructure, its development got the approval of the authority and the market has been operating since the $1990 \mathrm{os}$.

From an economic point of view, the whole settlement of migrants shrives with informal fishing enterprises. The fisheries supply more than half of the fish consumed in the city of Pointe-Noire. A vibrant migrant entrepreneurial enclave is now strongly and durably established in the rural periphery of the city. Obviously there are some differences in wealth within the migrant community. While the sea and the beach symbolize both the territory of men, the domestic space inside the courtyard is the territory of women. In economic terms, besides being a place of demographic reproduction and family matters, it is the place where women run their economic enterprises. These enterprises display a great deal of diversity, i.e. fish 
smoking, cake making, open-air cafeteria and so on. The internal setting of a courtyard housing migrant families speaks for itself with respect to the involvement of women in the running of micro-enterprises. Fish smoking in the generation of income for the household among women migrants with the increase in the fish production, the practice of smoking part of it has become a prominent incomegenerating activity within the community of West African migrants. Inside the courtyard, the dominant enterprise is fish smoking as it is by far the most lucrative one. The sale of fresh fish is mostly managed by fishermen themselves on daily basis either on the beach or in the different market places of Pointe-Noire. In contrast, women have built their own enterprises from what the male migrants do, suggesting a strong interdependency of livelihoods. As the next section further elaborates, the fishing activity among males is not entirely disconnected from that of women's. Taking advantage of a market niche, women migrants have specialized in fish smoking and salting to generate additional income for the household. It is worth pointing out that smoking fish is a widespread practice in most parts of Central and Western Africa. Lootvoet (1994) writing on the importance of small-scale fishing in Conakry (see also Ndiaye, 2000, for Senegal), reported a similar practice on the way in which women involved in fish marketing and smoking, get their supplies at the three wharfs closest to their homes. In Guinea local small-scale fishermen from the capital catch more than half of the small fish unloaded in the country, and area of Dixiin in Conakry is well known for this activity. However, in contrast to the situation in Pointe-Noire, the Guinean fishermen supplying fish are not married to women. Some of the women often make commercial arrangements with selected crews. They buy fish from the fishermen on daily basis (Lootvoet 1994). There are numerous similar cases on the continent of this fish smoking practice that finds roots in the traditional knowledge in food conservation. It allows the transformation of the excess of fresh fish into a product that can be conserved longer. By doing so, raw fish is not wasted while the added value is increased. Congolese women too have knowledge of this practice, especially in rural area. However, the practice has tended to decline among the female Congolese, especially among younger generations.

The herring is the fish mostly smoked by female migrants. Thus while they are excluded from fishing in sea, women are generally in charge of this practice. Indeed, with time, women have specialized in smoked fish, which they sell to the central market place of the city. Fishermen catch a lot during the dry season in Congo this season runs from May to September). This type of fish, cheaper than the other species and livestock meat, is a primary source of animal protein in the nutritional intakes of urban households. Although the equipment is rustic, it is very efficient from an economic point of view. From a technological point of view, the smoking process operates in a traditional way using wood, sawdust and equipment made with old metallic barrels. In every courtyard, one can find two to four units of this traditional equipment used for the smoking of fish. The smoking process is generally done in the night and the product is sold in the morning in the community market or in other market places around the city. 
With the expanding population of consumers in and beyond the city (the national urban growth rate is around 8 percent), the demand for smoked fish has gone up tremendously countrywide. This activity has consequently become very lucrative for female migrants. It is not exaggerate to say that monthly earnings generated from fish smoking are sometimes higher than those derived from selling fresh fish. For example, a crate of raw herring from the sea is sold at 6 500 CFA Francs (10 euros) in the local market while the same crate of fish once smoked would produce a return of 13 ooo CFA Francs (20 euros). In the recent years, women have also started producing salt fish, especially shark, which is in high demand not only among people in the hinterland of the country but, an more importantly, also due to demands from Asian consumers. In Asia, shark fins are so highly priced that trading in this type of fish has become a lucrative business. It is estimated that while in Pointe-Noire, a kilogram of shark fins is priced between 15000 and 20000 CFA Francs, on the Asian markets the same kilogram is priced from 150000 to 200 ooo CFA Francs (figures obtained from the interview with the head of the trading and outreach service of the regional fisheries department at Pointe-Noire, 2010). In line with the 1998 international regulation on shark fishing the government of Congo-Brazzaville issued in 2001 a prohibition on all species of shark fishing. This ban has since more or less affected the fishing migrant community. The prohibition was as well addressed to industrial fishing companies operating along the costal lines. Shark fishing gained in intensity in 1998. Years before, the consumption of shark was quite limited among the Congolese people. Traditionally only people from the ethnic group buvili consumed shark. Historically these people were the first settlers in the coastal region where Pointe-Noire is located. But with time and as migrant fishermen started to make use of more sophisticated fishing techniques (two of these being shark nets called locally "kouta" and powerfully motorised dugout canoes) and the discovery of lucrative markets, shark fishing grew up considerably. However, despite the national ban over shark fishing, the catches have gone up unchecked at such a point that sharks once abundant at sea, are now threatened of extermination around the coastal zone. With the use of intensive fishing techniques, fishermen have disrupted the reproductive patterns of sharks as they are catching more than the quantity permitted by the authorities for local consumptions. The illicit shark hunting and poaching by migrant fishermen has kept on gaining in intensity over the past years. Although statistics on sharks caught through nets are not available, the substantial increase in the number of dugout canoes used for this practice is a strong indication of the growing catches. From 25 in 1999 and 250 in 2000 (according to the official above), my fieldworks enumerated 475 dugouts in 2010. As of 2000, the government introduced permit for shark fishing to curb over fishing. This intervention has so far remained ineffective. The records available indicate a number of 151 shark-permits issued to migrant fishermen, far below the number of 475 dugouts operating along the coastal lines. The use of counterfeit permits is widespread among fishermen as one of their representative revealed me during the interview that "some of them don't have shark-fishing permits". Shark fishing is very lucrative for these migrant fishermen. According to the representative above "three days in fishing shark can produce earnings ranging between 45000 and 60 ooo CFA Francs". Once salted by women, these earnings could go up to 95 ooo CFA Francs. 
Smoked and salt fish are also wholesaled to Congolese traders who retailed it in other urban centres or rural localities. Women sell salted shark mostly to Western African traders, especially nationals from Senegal, who in turn resell it at high prices on Asian markets. In addition to fish processing, migrant women tend to diversify their sources of income. Moser and Holland (1997) rightly pointed out that diversification of livelihoods is one of the strategies used by vulnerable self-employed workers. For these women, diversifying is a way of venturing in activities that allow them to be partially independent in fish sourcing from their male partners. The profits generated from fish smoking are partially invested in retailing products of first need (cooking oil, sugar, salt, petrol, and so on). Other women run open-air restaurants inside the courtyard selling a variety of recipes reflecting the cultural tastes of fishermen. One can also find a few stalls selling manufactured or food products at the front door of the courtyard, on the sidewalk of streets. While the market for smoked fish is citywide even national, the market for this other type of micro-enterprises is mostly oriented to the migrant community. Customers are predominantly drawn from the same neighbourhood. Children are frequently called for in the running of this pettycommerce on the street. Depending on their age, they are at times assigned to bigger activities such as attending open-air restaurants that have proliferated around the place.

Enterprising as a group is not a common practice among these women. Because it is a home-based enterprise, the women migrants work alone in the operation of smoking fish. When required, they generally prefer to get assisted by very young girls, who call them Mama (meaning mother), in the running of the other income generating activities. Observations from the field reveal that not all the children assisting these women are so to say biologically related to them. Most of them are child migrants from the same areas where these women originated. Child migration is not a phenomenon specific to Pointe-No ire in Congo-Brazzaville. Continentally it is in the rise with a mixed bag of positives and negatives as reported in Hashim (2006). Child migrant labour is a common practice in West Africa, often covered under the traditional child fostering practice that has generated an intense induced-migration of children from the area of origin of fishermen. These female migrants tend therefore to reproduce this practice in countries where they relocate. During the fieldworks, I captured a greater involvement of these women in the education of their children than among male migrants. This is so for two reasons. First, women are strongly committed to the education of their own children. The income generated from sales of fish smoking is invested in their children's education. Thus for that reason, they do not involve them in the running of their smoking fish business as this implies time spent out of the school. Education is regarded within the migrant community as a way out of sea fishing for the younger generations. Second, family ties with the place of origin obligate foreign fishermen (or their wives) to foster children sent by relatives at home. Supposedly, these children migrate to Pointe-Noire in accordance with the customary obligations toward the ethnic group or the extended family that govern social relationships and family ties in many societies of Africa. Some of these children work inside the courtyard, and do not attend school. As the fish processing equipment is 
hard to handle for children of young age, these women also hire manual operators recruited among young Congolese who come every day on the beach to look for casual job.

One may query about the extent to which this form of enterprising reduces or perpetuates economic inequality between spouses. The following section examines this issue in details.

The positioning of women in the matrimonial relations among the social changes affecting the migrant fishing community, a development worth mentioning is the reconstruction of gender relations within the domestic space of the courtyard. In terms of setting up business partnership involving both men and women. Partnering in livelihoods diversification along the sexual lines is one of these aspects of social life where the differentiation is not apparent. Indeed, although on surface a sexual division of labour seems to prevail, strong linkages have taken place across the livelihoods of both male and female migrants in the form of an intra-household arrangement for the demand and supply of fish on daily basis. Within the community of migrants settled in Pointe-Noire, male fishermen rely on their spouses' enterprises in order to boost their own business. Conversely, inputs from husbands are the main drivers of women's enterprises. Arrangements around these interdependencies are very significant to the self-financing of fisheries. Being informal they actually do not qualify for the services offered by the formal credit-lending institutions supporting micro-enterprises. Within the fishers community migrant women therefore occupy a central position in the running of the fishing enterprise. One would say, without exaggeration, that they are present at both the up and down streams of the fishing activity. At the lower level, they are involved in fish smoking. The fish is supplied to women on daily basis when fishermen come back from sea. As was mentioned earlier, the income generated by women from their enterprises has an important economic function in the development of fishing activity. Being a two-site type of livelihoods, sea and courtyard, the fishery industry assigns a prominent role to the activity run by women. This is so because it brings additional income to the income men generate from the sea. In fact it is perhaps one of the reasons why fishermen value marital life. For migrant fishermen, women, and particularly their spouses, are key business partners in regard to the crucial role they play in their search for fortune. Most of the marriages are arranged from the country of origin in order to perpetuate this partnership. This was particularly the case for the first settlers. Marital union is so to say a mechanism through which the specific human capital, which both men and women represent, is used for the achievement of fortune abroad. The so-called chain migration brings in the male migrant first (generally unmarried) and thereafter the women migrant from the same area of origin through arranged marriage. Once the spouse has joined her husband in Pointe-Noire, she gradually becomes involved in fish smoking in order to earn money for herself and for the fishing activity of her husband. Her monetary contribution varies according to the requirements in canoe maintenance or acquiring fishing equipment. The purchase of a fishing net for example may require the full amount generated from sales to be given to the husband. 
Fish smoking is a widespread income-generating activity among female migrants within the community. Some women have been running this activity for more than thirty years. From the experience acquired, they are transmitters of know how in business practices. Recently arrived migrants learn how to start and run it from established entrepreneurs. This is the way they acquire the specific human capital mentioned in an earlier theoretical section. These women are also motivated by their husbands to get involved in this type of business as a way of increasing the household income. The married women I interviewed acknowledged the contribution of their husbands in the acquisition of the start up capital. They however indicated that they get involved in the business by necessity to create a kind of cash flow for the husband's business. The profits women generate from the processing of fish are partially or entirely credited to the financial resources of the husband to build up a rolling capital that may be used to cover recurrent costs and investments needed for the running of the fishing activity. In return, the husband provides, depending on the species, part or the entire fish catch to his wife for it to be smoked and sold at a higher price in the market places. This arrangement is part of the expectations migrant fishermen attach to co-ethnic marriage. Without denying the consideration derived by men from matrimony and the formation of a household as a family unit for reproduction, it seems obvious the reproductive significance of matrimony relations has receded into the backgrounds of transactional relations. Other pressing economic concerns and interests have gained importance in the relations between men and women within the fishing community. The nature of domestic relations is affected by the emphasis placed routinely on obligation and reciprocity rather than consideration and beneficence of marital union. The fishing activity of men at sea has increasingly become linked to the economic activity of women inside the courtyard. The latter partially provides the financial capital needed for the acquisition of additional technical capital to boost the fishing business. The interconnectedness of fishing at sea and the smoking of fish in the courtyard therefore entail an overlap of tacit obligations. Whether the fishing canoe is a collective property or individually owned, the responsibilities of a fisherman at sea are related to the funds generated by his wife from fish smoking at home. A poor performance in fish catching at sea harms the wife's business in the courtyard. In turn, insufficient financial resources generated from the fish smoking weaken the gains of the husband's fishing enterprise. A point of interest is whether fishermen sell the fish or give part of it to their spouses for smoking. To clarify this point it is relevant to bring in the study conducted by Boe (1999) on the same community. Boe reported that within the fishermen society (which Boe named Popa) in Pointe-Noire, there is a strong established gender-related transaction that exists to serve the economic interests of the couple. She argued that fishermen sell their fish to their wives at a price below the local market price. The wives process the fish (through smoking) and re-sell it in distant markets, making a profit they mainly re-invest in their husband's fishing activities. According to Boe, this arrangement impels both men and women to work hard in order to make the most of their respecttve enterprises. During my fieldworks, however, the informants Ispoke to did not confirm the "sell-and-buy" arrangement reported in Boe's study. What transpired instead is that the fish is given to the female spouse for her to run her own business and share the proceeds of the sales with the husband. One of the finalities of this arrangement around fish processing is the placement of the monies generated from smoked fish into the husband's business to cushion it against the adverse effects 
associated with the risky character of fishing: stormy weather conditions, strong waves and high tide, heavy swell, destruction of nets by predators, and so on. The woman can also invest her share of proceeds somewhere else or place it in one of the rotating saving arrangements established by women migrants in the community. The question is how much is left to her? The discussion section provides some elements of response to this question.

There are times however when women are faced with shortages of fish to smoke because of their husbands' misfortune at sea. Indeed, it is quite common that fishermen come back from sea with not enough catch to supply the spouse with raw fish. Once rare, this situation has increased in frequency due to over fishing and the growing presence over the past years of industrial fishing boats in Congolese waters. It is important to note that over fishing has a multifaceted set of causes, and one of these is the growing illegal fishing taking place in high sea. Chinese fishing boats are particularly involved in this practice, and this has prompted the government of Congo-Brazzaville to suspend some of them because of failure to respect the laws and regulation in force. For example, 69 Chineseowned boats were banned from fishing tor illicit activities in 2011 in the prohibited zone of up to six nautical miles offshore, which is set aside for reproduction and renewal of fish stocks. The recurrence of such unpredictable fish shortages has resulted in the diversification of source of fresh fish among women in order to protect their businesses against the risk of running out of fish. When shortage happens, using their savings or money generated from rotating savings, they buy fish from fishermen to whom they have no marital relations. In contrast to the transaction with the husband, the woman makes in this instance an upfront payment to the fisher. Both the buyer (the women) and the seller (the fisher) agree upon a convenient price based on various conditions in place. On the side of the female buyer, the price is determined by factors such as the amount of cash available, the capacity of the equipment used for the smoking and salting of fish and of course the maintenance of the household. On the side of the male fisher, the factors taken into consideration include the costs incurred in fishing at sea, mending of nets and equally making ends meet for the family. Importantly because both parties are from the same migrant community, cultural values are of great importance in negotiating a price. Although expressed by only a few women among the informants, the interviews suggest a certain preference for buying fish from fishers with whom they are not matrimonially linked. The reason for that is simply that they can keep a large portion of their sales for themselves. This may be a sign of search for autonomy among women migrants in the running of their enterprise.

\section{Discussion and some concluding remarks}

From the above analysis of gender-based arrangements around livelihoods, some meaningful insights emerge. As was argued in the theoretical framework, women migrants have been able to consolidate income-generating activities that are strongly linked to the fishing activities of their male counterparts. The fish smoking activity remains a quasi-monopoly of married women migrants though unmarried women (in smaller numbers) whose migration was induced by first settlers have also made inroads in this type of enterprise by learning from them. Surprisingly, it was observed that despite the fact that it is an activity mainly driven by operators with kinship within the community, these women however make minimal use of professional solidarity by 
linking up with other entrepreneurs. They mostly operate as self -employed workers within their respective courtyards, although they partner with their husband in the financing of the costs of fishing at sea. This is not to say that women traders do not socially interact among themselves on commercial or other community matters. For example the community-based market place mentioned earlier is a physical space where social interaction around collective interests is forged on daily basis. It also allows a certain mobilization of community and households resources toward greater betterment and representation of women within the community. From an entrepreneurial point of view, the fish smoking industry certainly contributes to increasing the capability for self-lifting within these female migrants. Some of them have even managed to acquire property in their country of origin. Needless to mention remittances they periodically send home to help relatives left behind.

Except the situation where the woman is buying fish from another fisherman, the arrangement around fish and money supply between spouses is not binding on the husband. It is first and foremost a marital arrangement that has a tacit degree of enforcement. The husband and wife involved have no, so to speak, equal power in this partnership. The former dictates how much he needs for his business and, sometimes, for other unrelated expenses. On her side, the wife is compelled to comply with the terms of this agreement more for the sake of keeping afloat the diversification of livelihoods in the household than looking at it as an equal opportunity partnership. Notwithstanding the possibility of non-compliance, women have maintained this type of arrangement as a way of getting their daily supplies of fresh fish to smoke without being asked to make upfront payments if they resort to outside suppliers.

Looking at this partnership from the angle of the reconstruction of gendered roles, the field observations suggest the perpetuation, through this arrangement, of a relation of dependence and subordination at the expense of the female partner. This is so because women involved in fish smoking and fishermen are intimately known to each other. Their professional relations, part of a much wider marital relationship, are therefore embedded in a system of many other reciprocal obligations to preserve the family interests along the patriarchal lines. Because of its very non-binding nature, this arrangement does not oblige the husband to share equitably or refund his wife the "loan" received from smoked fish sales. Thus, without giving a precise meaning to it, a concern can be raised about the implication of the arrangement described above for the emancipation of the women involved. During the fieldworks, it was also observed a certain reluctance among women to reveal detailed information on ways in which they share the profits with the husband and whether they too get subsidized in case of cash shortfall. This issue was deliberately avoided by almost all respondents, and it was therefore difficult to estimate the amount of the proceeds the woman keeps with her once her husband has taken his share. It is undeniable that within the marital cohabitation, there is a business-like venture or partnership between the female and the male migrants. Based on the nature of this partnership, as observed from the field, it is however hard to reject the view that the position of the woman is more of an entrepreneur working in the shadow of the husband. At any time, this latter can resort to his wife in order to obtain additional capital for his business using his position of household head. 
As widely documented in the literature on migration networks reviewed in an early section, this paper, by exploring some of the conditions under which female migrants run their fish smoking microenterprises in the costal zone of Congo-Brazzaville, has highlighted the prominent role played by social capital in setting up enterprise in the informal sector. As evidenced, women within that community rely heavily on their husbands in order to run their activities. They serve as social capital for these women. This confirms a point made in the theoretical framework. For that reason, male migrants represent a major stratum in the social networks women resort to in the process of establishing their business. Their microenterprises are by-products of a vibrant artisanal fishing industry established in the enclave by male migrants from the same origin. Therefore the livelihoods of male and female migrants are intertwined in that the former provide the primary input, which is thereafter processed by the latter and re-invested in the fishing business. At the difference of a female migrant working independently from the male partner, the interdependency is strong between the activities of male and female migrants within this community. It is an entrepreneurial venture which is very functional to the asset portfolio accumulation and sustainable livelihoods of the migrant household making a living out of the sea. This collaboration between spouses finds all its significance in the context where these fishing activities do not have access to formal micro credit suppliers. This domestic means of business capitalization is very critical as it sustains the generation of income through a diversification of livelihoods for the household within the fishing community. Viewed from a certain angle, it is an indication of reciprocity in self-financing of individuals.

Evidence is insufficient however to claim that enterprising is an indication of emancipation from the perspective of the women involved. It is however somewhat clear with the data at hand, that women may be constrained in translating their entrepreneurial capability into greater autonomy for control over the uses of their finances within the household or the community at large. There is little evidence from information gathered that success in generating income from fish smoking has resulted in more power gained and status improved within the household. The migrant community of these women remains predominantly patriarchal in terms of gender relations. Given the fact that men are likely to have position of heads, women are, so to say, still in a state of subordination within the household. Thus one can argue that even though the arrangement between husband and wife around fish trading is an indication of interdependency, it may as well be regarded as a contributing factor to prevailing gender asymmetries. Moser and Holland (199.71 argue that: "Strategies to reduce vulnerability sometimes imposes unequal burden on household members. Women because of their multiple responsibilities have frequently assumed disproportionate share of the burden of adjusting to adverse economic circumstances, limiting their ability to respond to new opportunities."

Finally, referring to the question of connection in spouses' livelihoods, this paper has in this regard demonstrated that women who migrate for marital reason may engage in a market niche that is not fundamentally different, though distinctive, from that of their husbands. Their activities add value to those run by their male partners and for that reason, a complementary dimension is established. The niche they insert 
in may require specific business practices and skills. In this case, these women make use of traditional means of production in practice in their place of origin to exploit the entrepreneurial opportunities in the sub-market into which they operate. In so doing, they do not require a big amount of capital to start up business. It is indeed a positioning by learned practice within the host society. Because they operate under low costs in the informal sector, these women have seized opportunities to expand their financial basis in the long run. Even if the migration was primarily motivated by marriage, it has had positive consequences on their capability to sustain means of livelihood and make a living in the host society. 


\section{BIBLIOGRAPHIE}

ADEPOJU A., 2008, Migration in sub-Saharan Africa, Current African Issues No.37, Nordic Africa Institute, Uppsala.

ARENIUS P. and MINNITI M. 2005, Perceptual variables and nascent entrepreneurship, Small Business Economics, 24, p.233-247.

BOE T., 1999, Access regime and institutions: the economic organisation of the migrant popo fishermen of Pointe-Noire, Congo, Working paper No.8, Christian Michelsen Institute, Bergen.

BOSMA N. and VAN PRAAG M.,2004, The value of human and social capital investments for the business performance of start-ups, Small Business Economics, 23 , p.227-236.

BROWN B. M., 1995, Africa's choices. After thirty years of the World Bank, St Yves pie, Penguin Books.

CARSRUD L., A. and OLM W., K., 1986, The success of male and female entrepreneurs: a comparative analysis, in SMILOR R. M and LOKHUR R. (eds). Managing take-off in fast growth firms, Praeger publishers, New York, p.147-162.

CASTLES S. and MILLER M. J., 2003, The age of migration: international population movements in the modern world, 3d ed., New York, Guilford Press.

DESPRADEL L.,1984, Internal migration of rural women in the Caribbean and its effects on their status, in UNESCO (edl, Women on the move: contemporary changes in family and society, Paris, UNESCO publications.

DIALLO A .. 2000, Status of fish stocks in Senegal, in ABBAN E.K., CASAL C.M.V., FALK T.M. and PULLIN R.S.V. (eds), Biodiversity and sustainable use of fish in the coastal zone, ICLARM Conference Proceedings.

DANA L.-P., and MICHAEL M., 2007, Towards---.a synthesis of immigrant and ethnic entrepreneurship, in DANA L.-P. (ed). Handbook of research on ethnic minority entrepreneurship. A co-evolutionary view on resource management, Cheltenham and Northampton, Edward Elgar Publishing, p.707-713.

FLOREZ, Elisa Carmen. 2006. Migration and the urban informal sector in Colombia, in TIENDA M. et al. (eds), African migration and urbanisation in comparative perspective, Johannesburg, Wits University Press, p.160-179.

HISRICH H. R. and BRUSH G. G., 1986, The woman entrepreneur: starting, financing, and managing a successful new business, Lexington, Mass, Lexington Books. 
LIGHT I. and BHACHU P. (eds). 1993, Immigration and Entrepreneurship, Culture, Capital, and Ethnic Networks, New Brunswick and London, Transaction Publishers.

LIGHT I. and ROSENSTEIN C., 1989, Demand factors in entrepreneurship. Paper presented at a conference on New forms of entrepreneurship under the auspices of the Research Committee on Economy and Society of the International Sociological Association, Milan

LOOTVOET B., 1994, Des palabres autour de quelques sardines : en faire un marche ? L'approvisionnement des fumeuses de bonga a Dixinn (Conakry), Cahiers des Sciences Humaines, Vol.30, $\mathrm{n}^{\circ}$ 1-2, p. 275-287.

LU Y .-H., 1984, Women, work and the family in developing society: Taiwan, in GAVIN W. J. (ed\}. Women in the urban and industrial work-force: Southeast and East Asia, Development Centre Studies Monograph No.33, The Australian National University, Canberra.

MASSEY D. et al., 1999, Worlds in motion: understanding international migration in the end of the millennium, Oxford, Oxford University Press.

MINNITI M. and NAUDE W., 2010, 'What do we know about the patterns and determinants of fema le entrepreneurshi $\mathrm{p}$ across countries?', European Journal of Development Research, 22 (3), p.277-293.

MOSER C., ANIS D. A (eds\}. 2008, Assets, livelihoods, and social policy, The World Bank, Washington, DC.

MOSER C. and HOLLAND J., 1997, Household responses to poverty and vulnerability. Vol. 4. Confronting crisis in Chawana, Lusaka, Zambia, Washington, D.C. Urban Management Programme, World Bank.

NDIAYE 0., 2003, International fish trade and food security-case of Senegal, in Report of the Expert Consultation on International Fish Trade and food Security, FAO fisheries Report n.708 FllU R708 (Enl, Roma, FAO publications.

PRESTON-WHYTE E. et al., 2006, Migration in the twenty-first century: conclusion, in TIENDA M., FINDLEY S., TOLLMAN S. and PRESTON-WHYTE E. (eds), African migration and urbanisation in comparative perspective, Johannesburg, Wits University Press, p.329-355.

PINGLE V., 2008, Microenterpr ise and sustainable livelihoods, in MOSER C. and DANI A. A. (eds\}. Assets, livelihoods, and socialpolicy, Washington, De, The World Bank,p.121-141.

RAZIN E., 1993, Immigrant entrepreneurship in Israel, Canada, and California, in LIGHT I. and PARMINDER B. (eds), Immigration and Entrepreneurship, Culture, 
Capital, and Ethnic Networks, p.97-124. New Brunswick and London, Transaction Publishers.

RODENBURG J., 1993, Migration and its socio-economic impact on women, their households and the village economy in North Tapanulli, Sumatra, Research report, Medan, Sumatra.

ROLDAN M., 1988, Renegotiating the marital contract: intrahousehold patterns of money allocation and women's subordination among domestic outworkers in Mexico city, in DWYER D. and BRUCE J. (eds.\}. A home divided: women divided: women and income in the third world, Stanford University Press, Sta'nford, California .

STRAUCH J., 1984, Women in rural-urban circulation networks: Implications for social structural change, in FAWCETT J. T. et al. (eds.), Women in cities of Asia: Migration and urban adaptation, Westview Press, Boulder and Colorado, p.6o-80.

TATI G. 2006 . Appropria tion of Land for Housing and African Immigrant Entrepreneurship in the city of Pointe-Noire (Congo-Brazzaville). (A Report prepared for and presented at the review workshop of the CODESRIA Multinational working group on Land in the Struggle for citizenship, democracy and development in Afr ica). Dakar, CODESRIA.

TRAGER L. 1984. Family strategies and the migration of women: migrants to Dapupa city, Philippines, International Migration Review, 18, p.1264-1278.

United Nations, 1993, Internal migration of women in developing countries, New York, United Nations.

VINOGRADOV E. and GABELKO M., 2008, Entrepreneurship among Russian female immigrants in Norway and their stay-at-home peers, Paper presented at the 4 'h European Summer University (ESU) in Bodo, Norway, 22-26 August . 